\title{
PERENCANAAN BERBASIS-KOMUNITAS DALAM REKONSTRUKSI ACEH PASCA-BENCANA: SEBUAH REFLEKSI TEORETIK
}

\author{
Erwin Fahmi ${ }^{1}$ \\ ${ }^{1}$ Magister Teknik Perencanaan - Universitas Tarumanagara, Jakarta \\ Surel: erwin.fahmi@gmail.com
}

\begin{abstract}
Dominant spatial planning theory and practice in the last half a century in Indonesia has been the rational comprehensive. This could be seen, among other, in the formal spatial planning works of the government and private sectors, and their underlying spatial planning laws, i.e. law 24/1992 and law 26/2007. This theory is based on the assumptions that the role of the state is central in the process of plan formulation and implementation; and, at the technical level, the availability of two main conditions to enable plan to be made, i.e.: necessary maps and statistical data, and relevant experts who interprete those data to meet the need of analysis. These assumptions, unfortunately, were not fully met in the specific case of post-conflict and post-disaster reconstruction of Aceh, especially during the first two years, 2005-2006. New approach, therefore, needed to be formulated, accepted by all reconstruction players and implemented to satisfy the immediate needs of the disaster'victims.
\end{abstract}

Keywords: planning theory, perencanaan partisipatif, rekonstruksi Aceh

\section{Abstrak}

Teori dan praktik perencanaan tata ruang yang dominan dalam setengah abad terakhir di Indonesia telah menjadi rasional komprehensif. Hal ini dapat dilihat, antara lain, dalam perencanaan tata ruang formal sektor pemerintah dan sektor swasta, dan hukum tata ruang yang mendasarinya, yaitu undang-undang 24/1992 dan undang-undang 26/2007. Teori ini didasarkan pada asumsi bahwa peran negara adalah sentral dalam proses perumusan dan implementasi rencana; dan, pada tingkat teknis, ketersediaan dua kondisi utama untuk memungkinkan rencana dibuat, yaitu: peta yang diperlukan dan data statistik, dan para ahli yang relevan yang menginterpretasi data tersebut untuk memenuhi kebutuhan analisis. Sayangnya, asumsi-asumsi ini tidak sepenuhnya terpenuhi dalam kasus khusus rekonstruksi Aceh pascakonflik dan pascabencana, terutama selama dua tahun pertama, 2005-2006. Karena itu, pendekatan baru perlu dirumuskan, diterima oleh semua pihak rekonstruksi dan dilaksanakan untuk memenuhi kebutuhan mendesak para korban bencana.

Kata kunci: teori perencanaan, perencanaan partisipatif, rekonstruksi Aceh

\section{PENDAHULUAN \\ Latar Belakang}

Teori dominan perencanaan spasial di Indonesia dalam setengah abad terakhir adalah teori rational comprehensive (lihat juga Sudaryono 2012: 4). Hal ini tercermin dalam peraturan-perundangan berkaitan dengan penataan ruang dan dokumen perencanaan yang dihasilkan. Dominansi ini tidak unik pada perencanaan spasial, namun juga pada perencanaan teknis lainnya, seperti perencanaan transportasi (Pardede dan Tetsuo 2008). Artikel ini akan membahas teori utama perencanaan spasial di Indonesia itu dan menunjukkan bahwa, pada satu kondisi spesifik tertentu, yaitu tahap awal 
rekonstruksi pasca-bencana di Aceh (2005-2006), teori dominan tersebut kurang tepat. Kekurangtepatan terjadi terutama karena ketidak-tersediaan instrumen-instrumen penopangnya, seperti peta, data, ahli dan lembaga negara pendukungnya, sementara tuntutan korban bencana untuk segera dibangunkan rumah dan infrastruktur lingkungannya, sangat kuat. Pendekatan yang justru efektif pada tahap-tahap awal itu adalah pendekatan perencanaan berbasis-komunitas, misalnya perencanaan desa (village planning, $\mathrm{VP}$ ).

Kajian ini disusun berdasarkan 3 sumber informasi utama, yakni:

a. Kajian kepustakaan tentang rational comprehensive theory dan pendekatan alternatifnya, yaitu pendekatan perencanaan berbasis-komunitas atau pendekatan partisipatif;

b. Sejumlah dokumen rekonstruksi Aceh pasca-bencana (dan pasca-konflik bersenjata), baik yang dihasilkan oleh BRR (Badan Rehabilitasi dan Rekonstruksi NAD-Nias), maupun pihakpihak lainnya; dan

c. Catatan pribadi, termasuk di dalamnya catatan selaku penanggung jawab koordinasi perencanaan spasial (termasuk perencanaan desa) di berbagai lembaga (Januari 2005 - April 2009).

Karena sebagian informasi berdasarkan pengalaman pribadi, maka, untuk menghindari bias, juga diadakan peer-review dari panel ahli untuk menguji interpretasi, analisis dan kesimpulan sementara yang dirumuskan dalam kajian ini. Untuk itu, draft naskah ini disampaikan kepada mereka secara tertulis untuk ditanggapi. Di antara reviewer terdapat pelaku perencanaan desa dalam rekonstruksi Aceh.

\section{RUMUSAN MASALAH}

\section{Teori dan Praktik Dominan Perencanaan Spasial di Indonesia}

Dominansi rational comprehensive planning theory dalam perencanaan spasial di Indonesia diperkirakan menguat pada paruh kedua dekade 1960-an, ketika pembangunan secara ahli (teknokratik) dipacu di Indonesia. Berbagai produk perencanaan spasial, seperti Master Plan DKI Jakarta 1965-1985 dan rencana yang sifatnya lebih teknis, seperti perencanaan transportasi (Pardede dan Tetsuo, 2008), dihasilkan. Rasionalitas dalam rational-comprehensive planning selalu dikaitkan dengan “... problem solving and decision making to guide state intervention." (Beauregard 2003: 111). Sementara, kemenyeluruhan (comprehensiveness) dipandang penting karena anggapan: makin menyeluruh suatu rencana maka makin baiklah rencana atau intervensi negara itu. Pilar intelektual perencanaan menurut penganut teori ini adalah " a set of procedures that would generate conceptual problems for theorists, serve as a joint object for theory and practice, and guide practitioners in their daily endeavors" (Beauregard 2003:111). Singkatnya, efektivitas intervensi negara dipastikan melalui penerapan prosedur perencanaan tertentu (lihat diagram di bawah).

Akar intelektual rational comprehensive theory dapat dilacak pada tradisi reformasi sosial dan tradisi analisis kebijakan (Friedmann 1987). Tradisi reformasi sosial memandang perencanaan sebagai upaya ilmiah yang dilakukan secara ahli, terjaga dari intervensi politik dan/atau intervensi warga kebanyakan yang tidak terinformasikan dengan memadai, dengan tujuan untuk meningkatkan pertumbuhan ekonomi, kesempatan kerja, dan pemerataan pendapatan. Sebagai "agent of development" peran negara sangatlah penting dan sentral dalam upaya tersebut. Untuk itu pula, negara juga menuntun masyarakat dengan melembagakan praktik perencanaan, agar tindakan-tindakan negara (dan masyarakat) dapat sinergis. Tradisi perencanaan lainnya, yakni analisis kebijakan, menurut Friedmann 
(1987), dipengaruhi oleh pemikiran Herbert Simon (1945/1997), yakni: bagaimana meningkatkan kemampuan organisasi (publik atau privat) untuk mengambil keputusan. Dengan mengikuti suatu prosedur baku tertentu, maka proses perencanaan dapat memberikan kepastian, baik tahap, durasi, maupun jenis masukan (input) yang diperlukan. Tradisi ini melihat pelaku perencanaan sebagai social engineer atau teknokrat, yang berperan mendorong, mengarahkan, dan/atau mengendalikan proses perubahan yang lebih inovatif secara berkesinambungan (Friedmann, 1987).

Di tingkat asumsi, tradisi kedua ini mengoreksi tradisi pertama. Tradisi pertama mengasumsikan adanya manusia rasional yang dapat memaksimalkan utilitas. Sementara, tradisi kedua justru beranggapan bahwa tidak ada manusia yang sepenuhnya rasional; manusia memiliki keterbatasan untuk bersikap sepenuhnya rasional. Inilah yang diistilahkan oleh Simon (1945/1997) sebagai rasionalitas terbatas (bounded rationality). Karena itu, asumsi tradisi kedua bukanlah economic man (yang memaksimalkan utility) tapi satisficing administrator, yaitu manusia yang dapat menerima pilihan yang terbaik di tengah sejumlah keterbatasan (Simon 1945/1997: 118). Pilihannya bukanlah first best, tapi second best. Aktornya tetaplah rasional, namun rasional dalam batas-batas yang dimungkinkan oleh keadaan.

Kritik terhadap rational comprehensive theory berpusat pada kecenderungan teori ini untuk mementingkan isi dan prosedur - sebagai konsekuensi dari perencanaan secara ahli dengan kandungan yang 'menyeluruh' -- daripada konteks (Beauregard 2003). Akibatnya, teori ini dipandang tidak realistis. Kuatnya peran organisasi birokratik-terpusat dalam proses perencanaan menjadikan penerapan teori ini juga dinilai tidak demokratik dan tidak sensitif terhadap kebutuhan dan/atau kepentingan pihak-pihak di luar lingkaran pengambilan keputusan. Konsekuensi selanjutnya, rencana yang dihasilkan menghadapi tantangan yang tidak ringan dalam implementasi, baik karena kualitas rencana maupun karena terbatasnya dukungan pihak-pihak yang kepentingannya tidak terakomodasikan.

Pemikiran rational comprehensive theory mewarnai UU Penataan Ruang No 24/1992 dan UU 26/2007. Menggunakan kriteria: sentralnya peran negara dan adanya prosedur perencanaan tertentu, berikut ditunjukkan kesamaan 2 UU tersebut dalam menerapkan kaidah rational comprehensive planning.

1. "Negara menyelenggarakan penataan ruang untuk sebesar-besarnya kemakmuran masyarakat" (pasal 24 UU 24/1992 dan pasal 7[1] UU 26/2007). Dalam penyelenggaraannya, kewenangan ini diberikan kepada Pemerintah dan Pemerintah Daerah (pasal 7 [2], pasal 8 [1], pasal 10 [1] dan pasal 11 [1] UU 26/2007); Hal ini juga berlaku pada UU 24/1992 (pasal 27 [1] dan 28 [1]);

2. "Rencana Tata Ruang Wilayah Propinsi ... merupakan penjabaran strategi dan arahan kebijaksanaan pemanfaatan ruang wilayah nasional ke dalam strategi dan struktur pemanfaatan ruang wilayah propinsi..." (pasal 21 [1). Begitu juga untuk RTRWK terhadap RTRWP (pasal 22 [1]). Arahan yang sama juga terlihat pada pasal 20 (3) UU 26/2007.

Berkaitan dengan prosedur perencanaan, meski setiap perencana tata ruang (planner) lazim merumuskan varian prosedur perencanaan spasialnya sendiri dengan mengacu pada UU Penataan Ruang yang berlaku, namun secara umum prosedur bakunya adalah sebagai berikut: 


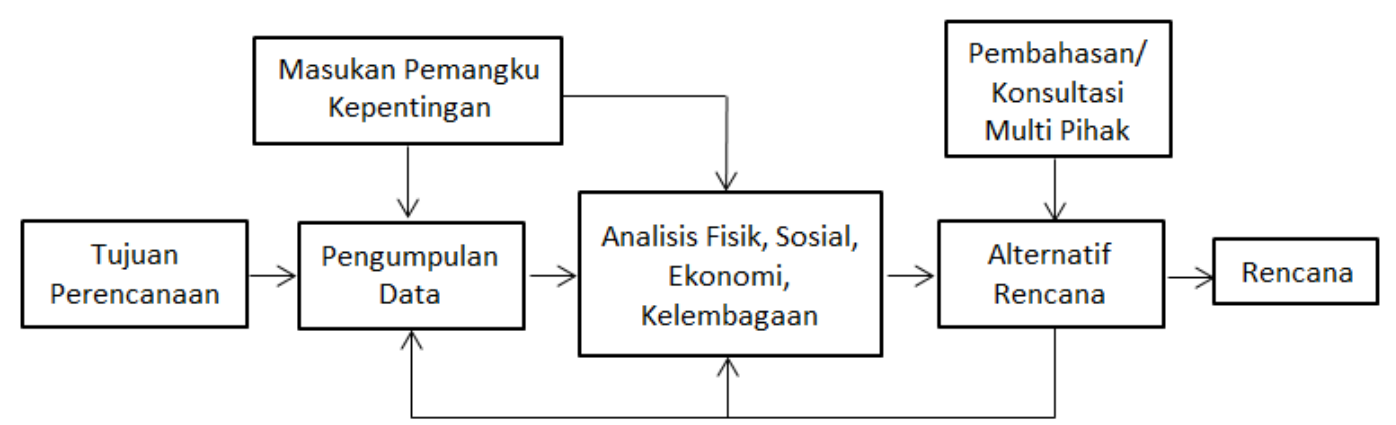

\section{Gambar 1. Diagram Prosedur Baku Perencanaan Spasial Menurut UU Penataan Ruang yang} Berlaku

Sebagai alternatif terhadap teori dan praktik dominan tersebut, berbagai kalangan di Indonesia, termasuk Pemerintah, juga menerapkan pendekatan perencanaan berbasis-komunitas, atau perencanaan partisipatif, meskipun terbatas. Secara epistemologis, pendekatan ini memiliki pondasi yang berbeda dibandingkan pendekatan sebelumnya. Mengikuti Purcell (2016), pondasi yang dimaksud adalah: sesuai prinsip demokrasi, setiap komunitas berhak menahan sebagian kewenangan yang (lazimnya) diserahkan kepada negara dan menggunakannya untuk mengatur dan mengurusdirinya sendiri. Termasuk mengatur dan mengurus-diri tersebut adalah menyusun dan mengesahkan rencana yang berkaitan dengan ruang hidup komunitas tersebut. Dalam konteks yang demikian, pendekatan ini memberdayakan (empowering) komunitas dan, karenanya, diharapkan dapat menjawab persoalan mendasar komunitas (Friedmann 1992).

Meskipun demikian, praktik perencanaan berbasis-komunitas bervariasi dalam hal kedalamannya. Arnstein (1995) menjelaskan variasi ini dalam apa yang disebut tangga partisipasi. Sebagian kalangan menerapkan perencanaan ini sesuai makna partisipasi - dari kata "to take part" -- yang sesungguhnya, yakni rakyat mengambil bagian dalam pengambilan keputusan dan kendali. Sementara, pihak lain memahaminya dalam pengertian yang sempit dan terbatas, yakni untuk 'mendidik' warga, sekedar untuk menginformasikan, atau untuk mendapatkan persetujuan. Mengikuti Arnstein (1995: 360), perencanaan berbasis-komunitas yang disebut pertama dinamakan "citizen power", sementara yang disebut terakhir adalah non-participation, atau maksimal tokenism. Karena pengalaman penerapan yang beragam dan terkadang terbatas tersebut, maka penerapan pendekatan perencanaaan berbasiskomunitas secara luas dan sesuai makna partisipasi, seperti dalam rekonstruksi Aceh pasca-bencana, tentu menimbulkan persoalan tersendiri, di antaranya kurangnya pendamping komunitas yang terampil.

\section{HASIL PENELITIAN DAN PEMBAHASAN \\ Tantangan Rekonstruksi Aceh}

Tantangan rekonstruksi Aceh bukan hanya membangun kembali rumah, gampong dan infrastruktur penopangnya. Namun, "rekonstruksi wilayah dan kehidupan masyarakat". Hal ini tercermin dalam judul Peraturan Pemerintah Pengganti Undang-undang (Perppu) No. 2/2005 tentang Badan Rehabilitasi dan Rekonstruksi Wilayah dan Kehidupan Masyarakat Provinsi Nanggroe Aceh Darussalam dan Kepulauan Nias Provinsi Sumatera Utara, atau disingkat Perppu tentang BRR -- yang kemudian dikokohkan menjadi UU No. 10/2005. Bahkan, Presiden Indonesia saat itu, Susilo Bambang Yudhoyono, menambahkan sasaran baru, yaitu membangun Aceh (dan Nias) yang lebih baik, "build back better" (BRR 2009). Dengan demikian, sasaran rekonstruksi selengkapnya menjadi: 
bagaimana membangun-kembali wilayah dan kehidupan masyarakat dengan cepat, tepat, sekaligus lebih baik.

Dari sudut pandang penataan ruang -- sebagai salah satu komponen utama rekonstruksi menurut UU 10/2005 pasal 5(a) -- tantangan rekonstruksi Aceh antara lain adalah:

1. Luasnya kerusakan: menjangkau areal sepanjang $\pm 800 \mathrm{~km}$ dengan tebal beberapa meter hingga $5 \mathrm{~km}$ (bergantung morfologi pantai), mulai pesisir Barat sampai pesisir Timur Aceh. Kota/kabupaten yang terkena dampak meliputi: Banda Aceh, Aceh Besar, Pidie, Bireun, Lhok Seumawe, Aceh Utara, Aceh Timur, Aceh Jaya, Aceh Barat, Aceh Selatan, dan Simeulue. Di sepanjang wilayah tersebut, hampir $3000 \mathrm{~km}$ jalan, lebih dari 100 jembatan, dan hampir $140 \mathrm{ribu}$ rumah, rusak atau hancur. Ini belum menghitung infrastruktur ekonomi lainnya, bangunan publik, sawah, dan sebagainya (Bappenas 2005). Karena skala yang luas dan massif ini maka, sejak awal, telah disadari bahwa rehabilitasi dan rekonstruksi tidak dapat dilakukan oleh Pemerintah Indonesia semata. Bill Nicol, seorang konsultan untuk Bappenas pada masa-masa awal pascabencana dan kemudian menjadi penasehat Kepala BRR, menulis: "the scale of the humanitarian catastrophe and physical devastation was too great for any one of the affected nations to manage on its own, with the possible exception of India. The global community opened its heart and walled in an outpouring of sympathy and support..." (2013: 50).

2. Untuk keperluan perencanaan spasial, Aceh pasca-bencana tidak memiliki peta dasar yang memadai, selain data statistic yang terbarukan. Beberapa penyebab: wilayah itu belum pernah dipetakan, petanya sudah tidak relevan karena berubahnya bentang alam akibat bencana, dan peta kepemilikan lahan yang rusak karena kantor BPN Provinsi juga terdampak tsunami. Masih berkaitan dengan hal ini, sebelum bencana, hanya provinsi dan Kota Banda Aceh yang memiliki rencana tata ruang (yang berlaku). Namun, akibat perubahan signifikan bentang alam pasca bencana, semua rencana tata ruang tersebut perlu direvisi (UU 24/1992 pasal 29 ayat [4]).

Penyebab utama terbatasnya peta dan rencana tata ruang ini adalah konflik bersenjata yang berlangsung hampir 3 dekade di Aceh. Situasi keamanan yang kurang kondusif mengakibatkan kedua aktivitas tersebut tidak dapat berjalan. Bahkan, sampai sebelum Kesepakatan HeIsinki ditandatangani (15 Agustus 2005), pekerjaan lapangan rehabilitasi dan rekonstruksi acap terganggu oleh kontak senjata antara pihak-pihak yang bertikai.

3. Luasnya lahan gampong yang tidak lagi dapat dibangun, umumnya karena telah terendam air laut, yakni dimiliki oleh 12.000 kepala keluarga (Steinberg 2007: 160). Artinya, bagi keluargakeluarga tersebut perlu disediakan lahan relokasi di tempat lain. Inilah alas an utama di balik pembangunan kota baru Beuramo di Kabupaten Aceh Besar (BRR 2009 [d]: 54-55).

4. Tantangan koordinasi: dari total US\$6.7B bantuan rehabilitasi dan rekonstruksi yang terealisasikan, kontribusi Pemerintah Indonesia kurang dari 1/3 ('hanya' 31,34\%), sementara lembaga-lembaga donor dan organisasi non-pemerintah (NGO internasional dan nasional) masing-masing 32,84\% dan 35,82\% (BRR 2009 [c]: 6). Keterlibatan banyak pihak dalam proses rehabilitasi dan rekonstruksi, dengan demikian, adalah suatu keniscayaan. Tantangan koordinasi berkaitan dengan beragamnya kemampuan teknis, dana, minat dan/atau kepentingan, bahkan wilayah kerja yang dipilih oleh masing-masing lembaga. Menurut Perppu 2/2005, BRR 
merupakan lembaga koordinasi; secara praktis, BRR juga bertugas mengisi celah (gap), baik wilayah maupun aspek atau sektor, yang tidak ditangani oleh pelaku rehabilitasi dan rekonstruksi lainnya. Persoalannya, dalam hal VP, meskipun Pedoman Perencanaan Desa (versi bahasa Indonesia; atau Village Planning Guidelines, versi bahasa Inggeris) telah disepakati bersama di antara pelaku-pelaku tersebut, juga telah disosialisasikan, tidak selalu dalam praktiknya pedoman tersebut dapat penuh diikuti. Sampai tingkat tertentu, masing-masing lembaga - yang memiliki sumber dana dan jalur pertanggungjawabannya sendiri - memiliki otonomi. Intervensi lembaga koordinasi baru dapat dilakukan jika komunitas dampingan mengeluh. Dalam hal VP, hampir tidak ada keluhan berkenaan dengan kelengkapan atau kualitas rencana desa.

Karena itu, di hadapan tantangan yang tidak kecil, pertanyaan awal yang harus dijawab adalah: rekonstruksi dimulai dari mana? (BRR 2009 [b]: 19). Pertanyaan ini lebih problematik lagi karena, jika mengacu pada UU Penataan Ruang (UU 24/1992), maka proses rekonstruksi harus berdasarkan suatu rencana tapak. Sementara, sebagaimana ditunjukkan pada diagram di bawah, proses penyusunan rencana tapak juga tidak bisa segera, karena untuk menyusunnya harus tersedia Rencana Teknis Ruang Kota (RTRK) sebagai acuan; untuk menyusun RTRK harus tersedia Rencana Detail Ruang Kota (RDTR). Demikian seterusnya, sampai Rencana Tata Ruang Wilayah Propinsi (RTRWP).

Untuk menyusun RTRWP, RTRWK (Rencana Tata Ruang Wilayah Kabupaten/Kota), RDTR, RTRK dan Rencana Tapak, dalam praktik masing-masing diperlukan waktu tidak kurang dari 6 bulan, ditambah proses pengesahan lebih kurang 2 bulan. Untuk seluruh jenjang perencanaan tata ruang, dengan demikian, diperlukan waktu tidak kurang dari 40 bulan, atau 3 tahun. Tentu saja durasi waktu ini tidak dapat diterima, mengingat penderitaan korban bencana. Terlebih pula, UU 10/2005 hanya memberikan jangka waktu 4 tahun bagi BRR untuk menyelesaikan seluruh mandatnya. Karena itulah, dengan mengindahkan ketentuan UU 10/2005, diperlukan terobosan dan inovasi dalam penataan ruang pasca-bencana ini. 


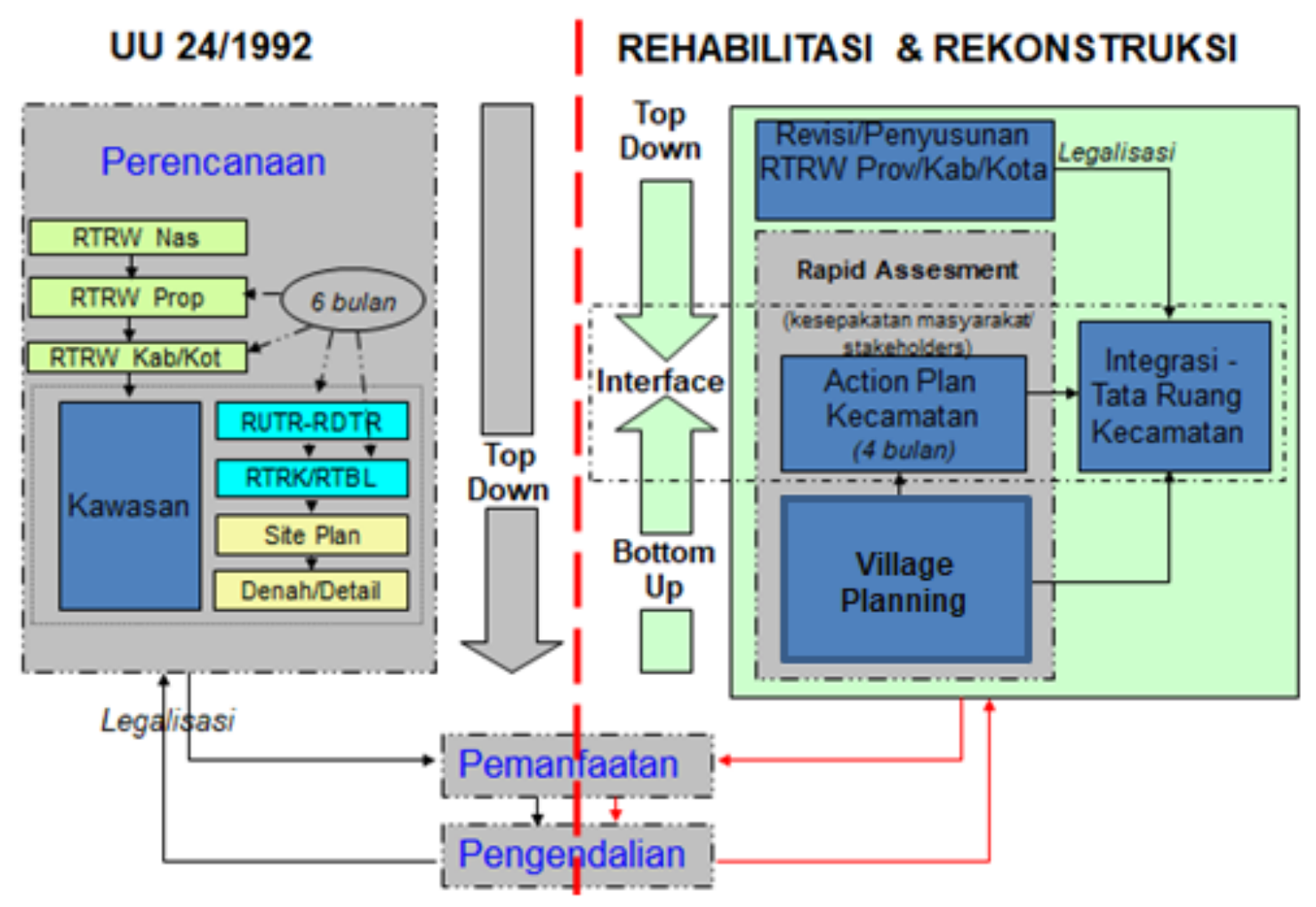

\section{Gambar 2. Bagan Kerangka Perencanaan Spasial dalam Rekonstruksi Aceh: UU 24/1992 vs Tantangan Rekonstruksi}

\section{Pendekatan Alternatif: Perencanaan Berbasis-komunitas}

Terobosan tata ruang dalam rekonstruksi dimungkinkan dengan bersandar pada UU yang lain. Jika asas penataan ruang adalah pemanfaatan ruang bagi semua kepentingan secara terpadu, berdaya guna dan berhasil guna, serasi, selaras, seimbang dan berkelanjutan (UU 24/1992 pasal 2 [a]), maka asas rehabilitasi dan rekonstruksi adalah: transparansi, akuntabilitas, partisipatif dan responsibilitas, dengan mendahulukan kepentingan umum dan bebas dari korupsi, kolusi dan nepotisme (UU 10/2005 pasal 6). Dengan asas mendahulukan kepentingan umum dan partisipatif, maka dapat diintroduksikan perencanaan desa (village planning, VP) sebagai terobosan dimaksud. Rencana desa nantinya dapat menjadi cetak-biru rekonstruksi rumah dan gampong; untuk rekonstruksi infrastruktur yang lebih teknis, seperti jalan lingkungan, dilengkapi dengan DED (Detailed Engineering Design). Hanya setelah kebutuhan mendesak mendirikan rumah terpenuhi, maka pada tahap berikutnya, dapat diupayakan integrasi antara rencana desa dan rencana yang jangkauannya lebih luas, termasuk RTRWK.

Pendekatan partisipatif dalam (pemetaan dan) perencanaan desa juga memiliki sejumlah alasan mendasar yang lain. Pertama, pendekatan ini sejalan dengan tradisi Aceh. Menurut tradisi, ureueng po rumoh (arti harfiah: pemilik rumah; arti kiasan: warga setempat) adalah pemilik otoritas etik untuk menentukan akan seperti apa, atau dengan cara bagaimana, rumahnya atau kawasan permukimannya 
nanti dibangun. Sementara, ureueng lingka (arti harfiah: tetangga; arti kiasan: pihak luar yang datang membantu) dapat saja memberikan bantuan atau fasilitasi, namun kewenangan pengambilan keputusan tetaplah berada di tangan ureueng po rumoh. Himbauan moral untuk menghormati tradisi ini telah, antara lain, disampaikan dalam Taushiyah Silaturrahmi Ulama-ulama Dayah se-NAD pada 8-9 April 2005. Kedua, UU 10/2005 juga menekankan keperluan dimaksud dalam Menimbang butir c: "bahwa penanganan rehabilitasi dan rekonstruksi harus dilaksanakan secara khusus, sistematis, terarah, dan terpadu serta menyeluruh dengan melibatkan partisipasi dan memperhatikan aspirasi serta kebutuhan masyarakat".

Pendekatan perencanaan berbasis-komunitas, seperti perencanaan desa, memang tidak tunggal atau unik. Beberapa lembaga, di antaranya UN-Habitat, telah menerapkannya pada rekonstruksi pascabencana di tempat-tempat lain dengan nama atau varian lain, seperti community action plan. Di lingkungan BRR, gagasan VP juga tidak berkembang sekali jadi. Diskusi awal telah berjalan bahkan sebelum BRR berdiri (wawancara dengan Junius Hutabarat, 2006 dan Andy Siswanto, 2006-07).

Sebagai akumulasi dari diskusi tersebut, pada Juni 2005 dikeluarkan pedoman BRR tentang:

a. Pedoman Pemetaan Tanah Partisipatif;

b. Manual Kesepakatan Warga tentang Batas Bidang Tanah, Kepemilikan dan Penanda Bidang Tanah dalam Peta; dan

c. Pedoman Perbaikan dan Pembangunan Perumahan,

Titik berat diberikan pada pemetaan karena disadari bahwa proses pemetaan (gampong) ini penting sebagai langkah awal sebelum perencanaan dapat dilakukan. Dalam perjalanan, karena disadari bahwa pedoman-pedoman di atas belum cukup spesifik berkaitan dengan VP, maka kemudian disusun pedoman VP yang lebih teknis dan operasional. Pedoman ini mengakomodasikan praktik yang sudah berjalan, baik oleh BRR maupun lembaga-lembaga pemberi bantuan lainnya, namun dengan memberinya standar yang lebih baik. Sebelum diproduksi dan disebarkan secara luas, pada awal April 2006 Pedoman (dalam 2 bahasa) ini dibahas dan disepakati bersama seluruh lembaga pemberi bantuan yang terkait. Pada April pula, Pedoman Perencanaan Desa (bahasa Indonesia) dan Village Planning Guidelines (Bahasa Inggeris), terbit. Dalam Kata Pengantarnya, Kepala BRR menyebutkan bahwa Pedoman baru ini merupakan pengembangan dari pedoman-pedoman sebelumnya.

Perencanaan desa (VP) yang dijalankan memiliki beberapa tahap sebagai berikut:

Tabel 1. Tahap Pelaksanaan VP

\begin{tabular}{lll}
\hline No & \multicolumn{1}{c}{ Tahap } & \multicolumn{1}{c}{ Catatan } \\
\hline 1. & Orientasi: tujuan perencanaan (VP), program R/R & Pada tahap ini juga dilakukan \\
& (rehabilitasi dan rekonstruksi), dan penyepakatan & pendataan beneficiaries, atau (calon) \\
& $\begin{array}{l}\text { tanggung jawab warga. Disepakati juga } \\
\text { perwakilan warga yang akan terklibat dalam } \\
\text { seluruh proses. }\end{array}$ & $\begin{array}{l}\text { jumlah rumah yang akan dibangun di } \\
\text { gampong tersebut. }\end{array}$ \\
& & \\
\hline 2. & Penyepakatan seluruh warga, apakah gampong \\
& akan tetap berdiri di lokasi semula, atau pindah ke & \\
\hline
\end{tabular}


tempat yang lebih aman (lebih ke darat,atau ke tempat yang lebih tinggi)

3 Relokasi atau tidak, umumnya VP dimulai dari pemetaan desa bersama warga. Pemetaan bertujuan untuk mendapatkan gambaran dan kesepakatan terutama tentang batas kapling rumah masing-masing warga. Batas ini harus mendapat persetujuan dari semua tetangga langsungnya

Pada VP di luar wilayah terdampak berat, sebagian (terutama yang disusun tahun 2007-dst) telah dilengkapi dengan pemetaan topografi untuk perencanaan yang lebih teknis (infrastruktur) dan sertifikasi lahan

\begin{tabular}{llllr}
\hline 4 & Pembahasan persama prasarana-sarana & Secara paralel, pendamping \\
lingkungan yang diperlukan dan perletakannya: & masyarakat/konsultan & juga \\
masjid, sekolah, pasar, balai desa, atau lainnya & melakukan pendataan & struktur \\
& & demografi, dll
\end{tabular}

5. Pembahasan tata letak rumah, prasarana-sarana lingkungan, dan lainnya

6. Pembahasan mitigasi bencana: vegetasi penyangga pantai, bangunan/bukit penyelamat (escape building/hill - bisa berupa masjid, atau bukit) di sekitar gampong

7. Pengesyahan VP oleh warga, berupa penandatanganan bersama lembar peta rencana yang tersedia.

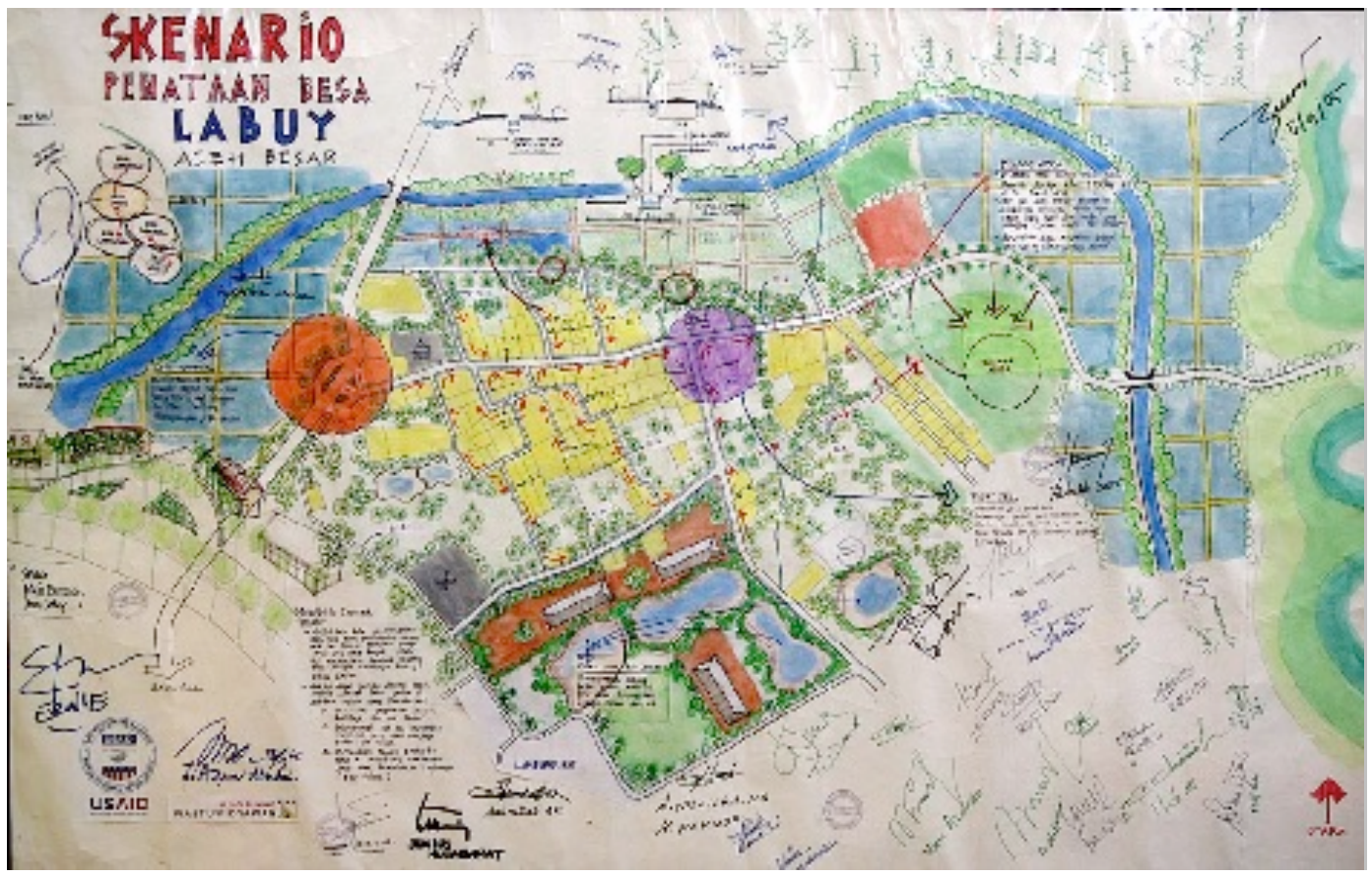

Gambar 3. Contoh Peta Rencana Desa yang Disahkan 
Penyusunan dan pengesahan VP memerlukan waktu yang bervariasi, bergantung keadaan komunitas dampingan, lembaga pemberi bantuan, dan sejumlah faktor spesifik pasca-bencana, seperti keberadaan pemuka gampong (geuchik, teungku meunasah dan tuha peut). Namun, secara umum, seluruh proses dari penyusunan rencana sampai pengesahan oleh warga dapat selesai dalam waktu berkisar 1-3 bulan.

Pengesahan rencana oleh warga memerlukan catatan tersendiri. Ada 2 alasan utama penerapan prosedur dan kewenangan pengesahan ini. Pertama, lumpuhnya Pemerintah Daerah akibat bencana. Kelumpuhan ini bukan saja karena rusaknya kantor dan arsip pemerintah daerah, namun aparatur pemerintah daerah juga merupakan korban bencana, baik dirinya maupun keluarganya. Sehingga, untuk waktu yang cukup lama, praktis pemerintah daerah tidak efektif berfungsi, termasuk untuk urusan yang berkaitan dengan pengesahan rencana tata ruang yang bersifat detail dan teknis tersebut. Kedua, memberi makna pada asas partisipatif dalam UU 10/2005 tentang BRR di atas. Amanat ini sejalan dengan pendekatan perencanaan berbasis-komunitas yang mengembalikan kewenangan komunitas untuk mengambil keputusan dan kendali hal-hal yang berkaitan dengan pemulihan wilayah dan kehidupannya. Menurut tangga partisipasi Arnstein, partisipasi ini berada di tingkat tertinggi (Arnstein 1995).

Tentu saja, meskipun setiap lembaga yang terlibat memberikan bantuan VP (BRR, lembaga-lembaga multi-lateral, seperti ADB, dan LSM, seperti Care International) telah menyepakati suatu pedoman bersama [yakni Village Planning Guidelines (BRR 2006)], namun variasi keadaan gampong (antara gampong di pesisir yang terkena tsunami dan gampong di pedalaman yang terkena gempa), tahun penyusunan VP, perkembangan kebijakan, dan lain-lain, tak terhindarkan juga menimbulkan variasi dalam proses dan hasil perencanaan yang lebih inovatif. Variasi tersebut antara lain:

1. Pada tahun-tahun awal (2005-2006), ketika pembangunan rumah sangat mendesak terutama di wilayah-wilayah yang rusak parah, maka VP umumnya belum dilengkapi dengan pemetaan topografi. Di desa-desa tersebut pemetaan topografi dilakukan kemudian, bersama program sertifikasi tanah dan rumah (= RALAS-The Reconstruction of Aceh Land Administration System);

2. Upaya untuk mengintegrasikan VP dengan rencana tata ruang yang cakupannya lebih luas, seperti RTRW Kabupaten/Kota, didorong mulai 2007 dan setelahnya, sesuai kemajuan penyusunan RTRWK itu sendiri;

3. Keadaan gampong yang disusun rencananya bervariasi, dari yang rusak-parah tersapu tsunami sampai yang 'hanya' terkena gempa. Variasi keadaan gampong ini mempengaruhi cakupan atau kelengkapan dokumen rencana desa (dibandingkan Guidelines). Pada gampong-gampong korban gempa, misalnya di Kabupaten Pidie, penekanan VP terutama pada upaya melengkapi infrastruktur gampong, tanpa banyak mengubah struktur spasial yang ada;

4. Variasi kedalaman dan kelengkapan VP juga ditentukan oleh keterlibatan pemangku kepentingan utama dalam proses VP, yakni warga komunitas. Dalam banyak kasus, pelibatan aktif warga ini juga tidak mudah, antara lain karena:

a. warga masih trauma dengan bencana yang menimpa anggota keluarga dan/atau warga satu gampongnya. Beberapa di antara mereka bahkan masih harus mencari anggota keluarganya yang hilang, atau terpencar di barak pengungsi yang berbeda; 
b. sebagian warga harus mencari tambahan penghasilan, antara lain melalui program cash for work yang dijalankan oleh UNDP. Sementara, lembaga yang memberikan bantuan VP umumnya tidak dapat menyediakan kompensasi bagi warga yang diminta untuk terlibat dalam proses VP tersebut;

c. beberapa lembaga pemberi bantuan, terutama yang relatif kecil, acapkali juga memerlukan waktu untuk mencari tenaga pendamping warga, atau berkonsultasi dengan induk lembaga/organisasi penyandang dananya, sehingga proses VP ikut terganggu;

d. warga terkadang juga tidak sabar dengan proses perencanaan dan konsultasi yang, di mata mereka, lama dan bertele-tele.

Sebagaimana juga dikemukakan oleh Steinberg (2007: 164), terdapat perbedaan kepentingan di sini. Di satu pihak, lembaga penyedia rumah (yang memfasilitasi proses VP) ingin menjalankan pendekatan partisipatif secara penuh. Sementara, di pihak lain, warga merasa bahwa penderitaan mereka di tenda dan/atau kemudian di barak pengungsi, sudah cukup berat. Mereka ingin rumahnya segera dibangun dan dapat mulai menata kehidupannya kembali.

Di tengah sejumlah tantangan yang dihadapi, sampai dengan 2009 BRR mencatat bahwa jumlah rencana desa yang diselesaikan oleh semua pelaku rekonstruksi mencapai 647 rencana desa, tersebar di semua kabupaten/ kota yang dicakup dan Nias (BRR 2009).

Apakah rencana desa tersebut efektif? Sebelum hasil-hasil evaluasi disajikan, patut dipahami terlebih dahulu apa yang populer di kalangan pekerja rekonstruksi sebagai "sambil berlayar membuat perahu". Maknanya, tidak ada cetak-biru rekonstruksi yang sepenuhnya dapat diikuti. Beberapa langkah, bahkan 'ditemukan' dan dirumuskan dari tantangan nyata di lapangan. Meskipun hal ini bukan pembenaran, namun konteks ini perlu disadari untuk memahami derajat pencapaian yang diperoleh.

Beberapa studi telah mengkaji efektivitas VP bagi rekonstruksi di tingkat gampong. Dua di antaranya adalah studi Grace Y. Harahap (2012) di Banda Aceh dan kajian BRR di seluruh kabupaten/kota terkait. Studi Grace Harahap tentang efektivitas proses partisipatif dalam VP terhadap pemulihan gampong dan komunitasnya menunjukkan: (1). Proses fasilitasi berhasil mencapai tujuan yang diinginkan, yakni mendorong keterlibatan aktif warga dalam proses penyusunan dan implementasi rencana. Namun, beberapa ketidaksetujuan dan ketidakpastian juga menunjukkan bahwa proses fasilitasi yang terbatas menyisakan isu yang belum selesai; dan (2). Komunitas mengakui bahwa kemampuan mereka terbatas untuk mendorong pemulihan ke tahap selanjutnya, tanpa bantuan dari luar (Harahap 2012: 194-6).

Studi kedua, yakni yang diselenggarakan oleh BRR, bertujuan memonitor dan mengevaluasi (monev) samples 346 VP, yang dipilih secara uji petik (BRR 2009: 10). Monev dilakukan terhadap 2 hal, yaitu: (1) evaluasi kesesuaian dokumen rencana desa dengan pedoman VP; dan (2) evaluasi implementasi rencana desa. Dengan mengambil monev di Kabupaten Aceh Besar (kabupaten dengan jumlah desa terbesar yang di-monev, yaitu 86 desa) sebagai ilustrasi, dapat disimpulkan:

a. Evaluasi atas dokumen VP. Secara keseluruhan, sebagian besar desa (54 desa, atau 63\%) tingkat kesesuaian dokumen VP-nya masuk kategori tinggi, 22 desa (25\%) masuk kategori sedang, dan 10 desa (12\%) masuk kategori rendah. Kesesuaian tinggi adalah jika ditemukan maksimal $25 \%$ dari butir-butir yang terdapat dalam dokumen rencana desa tidak sesuai dengan Pedoman. 
Kesesuaian sedang adalah jika ditemukan 25-75\%; kesesuaian rendah jika $>75 \%$. Angka tertinggi kesesuaian, yaitu $0 \%$, terjadi di desa-desa yang difasilitasi oleh Mercycorps, sebuah LSM Internasional yang berbasis di USA; angka terrendah, yaitu 78\%, terjadi di desa yang difasilitasi oleh Up-link, suatu kelompok yang dimotori oleh Urban Poor Consortium (UPC)-Jakarta;

b. Evaluasi atas implementasi program VP. Dari 3.987 butir program di 86 desa, sebanyak 1.377 atau 34,54\%, belum dilaksanakan atau tidak sesuai antara implementasi dan dokumen rencana desa. Kesesuaian tertinggi terjadi pada bidang rehabilitasi-rekonstruksi alam dan lingkungan, yaitu deviasi 'hanya' 1,22\%; kesesuaian terrendah terjadi pada bidang ekonomi lokal dan livelihood, yaitu deviasi masih 51,30\%.

Hasil monev di atas menunjukkan bahwa, sampai tingkat tertentu yang cukup tinggi, Pedoman VP telah menjadi pedoman bagi para pelaku VP. Tentu Pedoman VP itu sendiri belum sepenuhnya sempurna, sebagaimana perjalanannya sendiri (2006 - 2009) yang juga mengalami penyempurnaan implementasi yang lebih kreatif dan inovatif dari tahun ke tahun. Demikian pula, implementasi rencana desa, di tengah situasi rekonstruksi yang melibatkan banyak pelaku dengan tingkat otonomi yang relatif tinggi, membuat penyimpangan, dalam batas-batas tertentu, tak dapat dihindarkan. Pragmatisme warga komunitas, yang menginginkan rumah dan infrastruktur gampongnya segera terbangun, juga berkontribusi.

\section{KESIMPULAN DAN SARAN}

Artikel ini tidak berpretensi menegasikan rational comprehensive planning theory. Berbagai rencana dalam rangka rehabilitasi dan rekonstruksi Aceh pasca-bencanapun, sebagaimana diobservasi oleh Pardede dan Tetsuo (2008), juga menggunakan pendekatan dan teori yang berbeda, termasuk rationalcomprehensive. Penekanan yang diberikan di sini adalah bahwa pada suatu kondisi spesifik tertentu, terbukti bahwa rational-comprehensive theory, berikut peraturan-perundangan yang mendasarinya, kurang tepat diterapkan; dan sebaliknya, pendekatan partisipatif justru lebih sesuai.

Esensi "...to link scientific and technical knowledge to actions in the public domain" sebagaimana disarankan oleh Friedmann (1987: 38; 2011: 4) juga mendapat relevansi yang mendalam dalam rekonstruksi Aceh pasca-bencana tahap awal, 2005-6. Interaksi intensif antara warga dan fasilitator VP, acapkali melahirkan 'inovasi' yang tak terduga. Contoh: pemetaan partisipatif dalam penyusunan VP di salah satu gampong di Kecamatan Leupung - Aceh Besar, yang difasilitasi oleh UN-Habitat, pada 2005 dapat berjalan efektif, meski alat yang digunakan hanya kompas dan meteran gulung. Sampai akhir proses VP, tidak terdengar keluhan atau sengketa warga berkenaan dengan batas persil, atau semacamnya. Demikian pula, pengertian mendalam transactive planning (Friedmann 2011: 15 26), yang menekankan pentingnya komunikasi terus-menerus antara perencana dan pelaku-pelaku lainnya dalam proses perencanaan dan implementasi, mendapat tempat dalam proses ini.

Dari pengalaman perencanaan yang cukup kaya tersebut, meskipun spesifik pada konteks Aceh dan pasca-bencana, kiranya dapat memberi pelajaran bahwa peraturan perundangan dan praktik perencanaan spasial yang saat ini masih berjalan di Indonesia, yang didominansi teori rational comprehensive planning, yang berjalan seiring dengan dominansi peran negara, perlu dimoderasi. Moderasi terpenting adalah pengayaan khasanah, yang dilakukan dengan memberi ruang gerak yang 
cukup bagi sektor masyarakat untuk berperan menyejahterakan warga dan komunitas melalui perencanaan berbasis-masyarakat dengan berbagai pemikiran kreatif mereka.

Sementara, spesifik berkaitan dengan pendekatan perencanaan berbasis-komunitas, tidak dinafikan bahwa sementara pihak masih mempertanyakan efektivitas (politik)nya (lihat, antara lain Monno dan Khakee 2012). Kecenderungan pendekatan ini untuk mencari konsensus, titik tengah, menutup peluang pendekatan ini untuk menggugat dan menantang wacana dan ortodoksi yang merugikan kepentingan kelompok terpinggirkan (Crystal 2017). Namun, pengalaman VP di Aceh pasca-bencana tidaklah demikian. Pengalaman tersebut jelas menunjukkan bahwa peran sentral negara dan ahli terbatas vis a vis peran komunitas. Selain itu, pendekatan ini juga membantu komunitas dampingan memulihkan permukiman dan trauma melalui keterlibatan dalam proses perencanaan dan implementasi rencana.

Upaya pemulihan wilayah dan kehidupan masyarakat Aceh pasca-konflik dan pasca-bencana terus berlanjut setelah 2009, tahun terakhir rekonstruksi menurut UU 10/2005. Dengan penyempurnaan di sana sini, dokumen rencana desa tentu dapat menjadi pedoman bagi pembangunan desa. Terlebih melalui pemberlakuan UU 6/2015 tentang Desa, ketika desa di seluruh Indonesia mendapat kucuran dana yang relatif besar, maka perencanaan desa menjadi suatu keniscayaan. Untuk keperluan tersebut, guidelines dan pengalaman perencanaan desa dapat menjadi model untuk dikaji, dikembangkan dengan perubahan atau kreatifitas yang lebih baik dan diterapkan secara berkesinambungan.

\section{REFERENSI}

Arnstein, Sherry R. 1995. “A ladder of Citizen Participation”. Dalam Jay M. Stein. Classic Readings in Urban Planning, An Introduction. New York. Mc Graw-Hill. Pp. 358-375

Bappenas and The International Donor Community. 2005. Indonesia: Preliminary Damage and Loss Assessment - The December 26, 2004, Natural Disaster. A Technical Report Prepared for The Consultative Group on Indonesia Meeting, January 19-20, 2005

BRR. 2006. Village Planning Guidelines. Banda Aceh: BRR

BRR. 2009 [a]. Tsunami - Habis Bencana Terbitlah Terang. Jakarta: Seri Buku BRR

BRR. 2009 [b]. Kisah - Perahu yang Dilarungkan. Jakarta: Seri Buku BRR

BRR. 2009 [c]. Keuangan - Tujuh Kunci Pengelolaan Dana Bantuan yang Efektif. Jakarta: Seri Buku BRR

BRR. 2009 [d]. Perumahan - Membentang Atap Berpilar Asa. Jakarta: Seri Buku BRR

BRR. 2009. "Memori Akhir Tugas Bidang Lingkungan dan Tata Ruang, Kedeputian Infrastruktur, Lingkungan dan Pemeliharaan”. Laporan (tidak dipublikasikan). Banda Aceh: BRR

Friedmann, John. 1987. Planning in the Public Domain: from Knowledge to Action. Princeton: Princeton University Press;

Friedmann, John. 1992. Empowerment: The Politics of Alternative Development. Cambridge: Blackwell Publisers

Friedmann, John. 2011. Insurgencies: Essay in Planning Theory. London: Routledge 
Harahap, Grace Y. 2012. "Community Enhancement Through Participatory Planning: A Case of Tsunami-Disaster Recovery of Banda Aceh, Indonesia”. Unpublished Dissertation. Penang: Universiti Sains Malaysia.

Hudson, Barclay M. 2007. "Comparison of Current Planning Theories: Counterparts and Contradictions". Journal of the American Planning Association.

Legacy, Crystal. 2017. "Is There a Crisis of Participatory Planning?”. Planning Theory Vol. 16 (4) 425-442

Monno, V dan Khakee, A. 2012. "Tokenism or Political Activism? Some Reflections on Participatory Planning". International Planning Studies 17 (1): 85-101

Nicol, Bill. 2013. Tsunami Chronicles: Adventures in Disaster Management. Self-publication.

Pardede, Togu Santoso dan Tetsuo, Kidokoro. 2008. "Aceh Reconstruction Planning, Top Down or Bottom Up Approach? An Overview of Planning Theory and Learning From Community Planning in Aceh After Tsunami”. Paper presented at the 7th Asian City Planning, City Planning Institute of Japan, November 30. Tokyo

Purcell, Mark. 2016. "For Democracy: Planning and Public Without The State". Planning Theory Vol. 15 (4) $386-401$

Simon, Herbert A. 1997 (1945). Administrative Behavior: A Study of Decision Making Processes in Administrative Organizations. $4^{\text {th }}$ edition. New York: The Free Press

Steinberg, Florian. 2007. "Housing Reconstruction and Rehabilitation in Aceh and Nias, Indonesia Rebuilding Lives”. Habitat International 31 (2007) 150-166

Sudaryono. 2012. "Fenomenologi Sebagai Epistemologi Baru dalam Perencanaan Kota dan Permukiman". Pidato Pengukuhan Jabatan Guru Besar pada Fakultas Teknik Universitas Gadjah Mada. Yogyakarta: UGM. 